\title{
Allozymic variability in the Iceland scallop Chlamys islandica: geographic variation and lack of growth-heterozygosity correlations
}

\author{
Svein Erik Fevolden \\ Department of Aquatic Biology, Norwegian College of Fishery Science, University of Tromsø, N-9037 Tromse, Norway
}

\begin{abstract}
Populations of the Iceland scallop Chlamys islandica from the waters off Jan Mayen, Spitsbergen, Bear Island and northern Norway were investigated for allelic variation at 6 polymorphic gene loci. The 3 loci encoding for glucose phosphate isomerase (GPI), phosphoglucomutase (PGM) and superoxide dismutase (SOD) substantiated earlier findings of exceptionally high polymorphism at these loci in the Iceland scallop, higher than for many other pectinids. Loci encoding for malate dehydrogenase (MDH) and leucine-aminopeptidase (LAP) also exhibited higher polymorphism than is known for other pectinids. The high variability at an increasing number of enzyme coding loci for the subarctic/arctic species appears to contrast with predictions of negative correlations between environmental homogeneity and gene polymorphism. Allele frequencies at Mdh, Pgm and Sod varied between populations over the geographical range surveyed, giving supportive evidence of at least partial geographic isolation between stocks. Data of the present study do not provide evidence that multiple-locus or single-locus heterozygosity affect longevity of $C$. islandica. Heterozygosity did not increase with age of the scallops, nor were positive growth-heterozygosity correlations demonstrated, either at singlelocus or multiple-locus heterozygosity. This contrasts with findings for several other bivalves, but is in accordance with observations for other pectinids
\end{abstract}

\section{INTRODUCTION}

A previous study of allozymic variation in the commercially exploited Iceland scallop Chlamys islandica (O. F. Müller) from the northern Atlantic revealed that there was geographic variation in allele frequencies of 3 highly polymorphic enzyme coding loci, Gpi, Pgm, and Sod (Fevolden 1989). The most likely reason for inter-region variation in gene frequencies of C. islandica was suggested to be restricted gene flow, with a possible contribution from selective constraints (Fevolden 1989). This arctoboreal bivalve is the most common scallop species in Atlantic sub-Arctic and Arctic waters (Ekman 1953, Wiborg 1963, Waller 1991) and has a large dispersal potential due to its long planktonic larval stage (>2 mo, Gruffydd 1976 , Wallace 1982). C. islandica may be found in relatively deep water (down to $150 \mathrm{~m}$ depth; Ekman 1953) in environments of stable and low temperatures.
Although temperature varies spatially within the geographic range of this species (summer temperatures vary between 0.5 and $5{ }^{\circ} \mathrm{C}$ among areas sampled in the present study; Fevolden 1989), seasonal variations in temperature may be minor. C. islandica seems to be typical of more stable thermal environments than the other pectinids that have been examined electrophoretically for enzyme polymorphism. Members of the Pectinidae, in general, exhibit high polymorphism at specific enzyme coding loci (Beaumont 1991), but none of the examined species has shown greater variation than $C$. islandica at corresponding loci. The extremely high level of variation found at specific gene loci of Iceland scallop contrasts with earlier findings relating to levels of genetic variation in species inhabiting marine cold-water regions.

To provide more data on the genetic variation of the Iceland scallop, both within and among populations, additional sampling sites and more polymorphic loci 
have been examined in the present study. Samples from the northernmost commercial sampling ground for Iceland scallop, Moffen, north of Spitsbergen, were assayed together with those taken at a locality off the coast of northern Norway. Scallops were also resampled from sites at Jan Mayen and Bear Island.

The high heterozygosity of Chlamys islandica also makes the species suitable for studying possible relationships between heterozygosity and growth. This is a much debated theme for marine bivalves (see Zouros et al, 1988, Zouros \& Mallet 1989) and an important factor to be elucidated, especially with respect to commercial cultivation.

\section{MATERIAL AND METHODS}

Iceland scallops for biochemical genetic analyses were sampled randomly from dredges of scallops taken during assessment surveys conducted in 1988 (Jan Mayen, Moffen and Anddammen) and 1989 (Bear Island; Fig. 1). Scallops from Jan Mayen and Moffen samples were taken for size and age determination. Shell size was measured as the distance from the hinge to the opposite edge using an electronic sliding calliper. The age of individual scallops was estimated by counting growth rings in the shell hinge ligament as described by Johannesen (1973). Scallops were sexed by examination of gonads.

The adductor muscles and gonads were dissected from fresh specimens and immediately frozen at

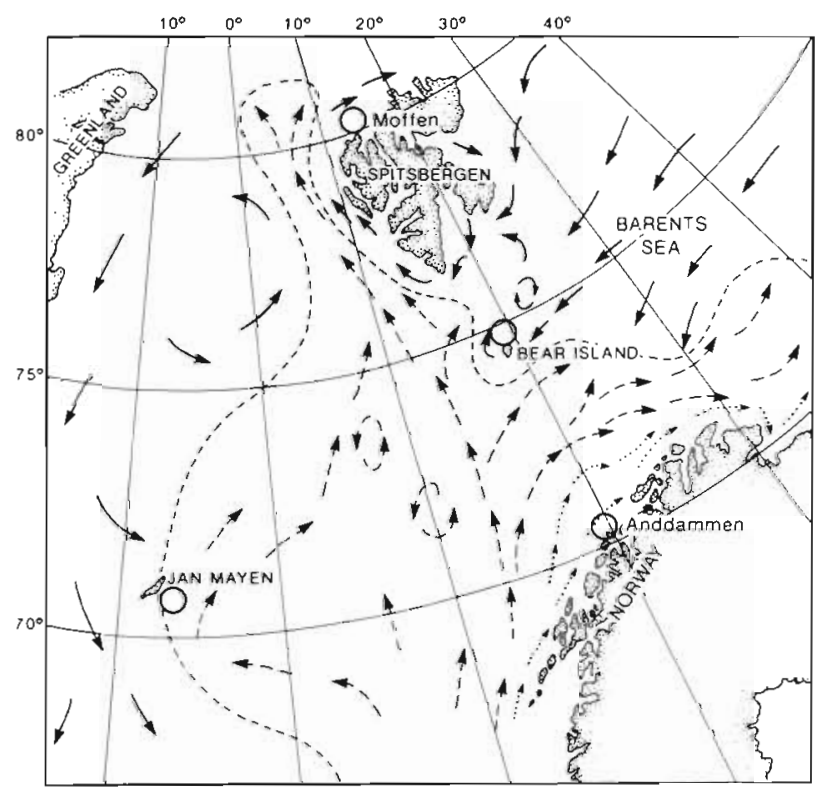

Fig. 1. Chlamys islandica. Sampling sites encircled. Surface currents indicated are: $(-\rightarrow)$ : Atlantic currents $(\longrightarrow)$ : polar currents; $(\cdots \cdots)$ : Norwegian coastal currents $-80^{\circ} \mathrm{C}$. Procedures for preparation of homogenates for electrophoresis and for the electrophoretic assay of glucose phosphate isomerase (GPI; E.C. 5.3.1.9), phosphoglucomutase (PGMi E.C. 2.7.5.1) and superoxide dismutase (SOD; E.C. 1.15.1.1) were described by Fevolden (1989). Leucine aminopeptidase (LAP, used to designate enzymes that are able to hydrolyse the substrate L-leucyl- $\beta$-naphthylamide-HCl; E.C. 3.4.11.-), and malate dehydrogenase (MDH; E.C. 1.1.1.37) followed the procedures of Fevolden \& Ayala (1981). The Tris-citric acid gel buffer ( $\mathrm{pH}$ 8.5) and lithium hydroxide: boric acid electrode buffer ( $\mathrm{pH} 8.1$ ) of Ridgway et al. (1970) were used for the LAP assay; the $0.002 \mathrm{M}$ citric acid gel buffer ( $\mathrm{pH} 6.0$ ) and $0.04 \mathrm{M}$ citric acid electrode buffer ( $\mathrm{pH}$ 6.1) of Clayton \& Tretiak (1972) were used for the MDH assay. All buffers were $\mathrm{pH}$ adjusted with $n$-(3-aminopropyl)morpholine.

The different alleles were assigned values which indicate their mobility relative to the commonest allele (100). Conformity to Hardy-Weinberg equilibrium of genotype distribution was tested using chi-square statistics for goodness of fit and by calculating Wright's fixation index of individual alleles in each subpopulation ( $F_{I S i}$ Wright 1965). Calculation of $F_{I S}$ (following the nomenclature of Nei 1977 ) was facilitated by using the population genetics computer program BIOSYS-1 (Swofford \& Selander 1981). FIS of each allele is calculated by pooling all remaining alleles so that a 2 -allele system is applied; thus, significance of $F_{\text {tS }}$ was tested by calculating $\chi^{2}$ as $F_{\mathrm{IS}}{ }^{2} N$ where $N$ is sample size (see Li 1955). Inter-subsample, inter-region, and inter-yearclass heterogeneities in allele frequencies were tested by contingency table chi-square analyses. Rare alleles were pooled so that no cells in the $r \times c$ tables had expected numbers less than 1 and cells with expected numbers less than 5 never exceeded $20 \%$. To avoid cells with low expected numbers when testing allele frequency differences between year-classes, the number of classes included was restricted to those listed in the legend of Table 3.

Contingency chi-square analyses were also applied for testing possible variations in single-locus or multiple-locus heterozygosity with age. In order to have the older and less frequent year-classes included in this analysis, year-classes were grouped as indicated in Fig. 5. Four of the polymorphic loci were used for testing age-heterozygosity correlations (Lap loci were excluded; see below), so 5 heterozygosity classes (0 to 4 heterozygous loci) were possible. The degrees of freedom in Table 4 show where pooling of heterozygosity classes was necessary to avoid $r \times c$ cells with low expected numbers.

The ratio of size/age for individual scallops was used as an index of growth and was calculated for indi- 
viduals aged up to $13 \mathrm{yr}$, the rapid growth phase of the species. To meet the requirements of normality the size/age ratio was log-transformed. For testing differences between mean growth of heterozygotes and homozygotes at single loci, $t$-tests and 1 -way analysis of variance (ANOVA) were performed. ANOVA was also used to test differences for growth among scallops of the 5 heterozygosity classes.

\section{RESULTS}

\section{Biochemical analyses}

The gel expression of loci coding for GPI, SOD and PGM were as described in Fevolden (1989). The monomeric enzyme LAP and the dimeric MDH were not scored in the previous investigation due to weakly stained bands. Alternative buffer systems used in the present study gave better resolution for these 2 enzymes, although LAP, which is encoded at 2 loci, could only be scored for a limited number of scallops (in particular the numbers were low in the Anddammen and Jan Mayen samples). The activity of the Lap locus of Chlamys islandica is reduced upon storage, and it also seems to be more temperaturesensitive than the activity of the other investigated enzymes of this scallop.

Allelic frequencies and frequencies of heterozygotes in scallop samples from the different areas are shown in Table 1. Relatively few significant $F_{15}$ values were scored, indicating general conformity to HardyWeinberg expectations for random mating populations. The significant $F_{15}$ values that were encountered were in all cases but one the result of an excess of homozygotes (positive values of $F_{I S}$ ) and a corresponding deficit of heterozygotes. The only Pgm deviation (Anddammen) and the Sod deviation at Moffen were caused by the presence of 1 rare homozygote in each case. The significant $F_{1 \mathrm{~S}}$ 's at the Lap-1 locus at Moffen were also the result of excesses of homozygotes of the respective alleles, but this could in part be due to secondary modifications of the enzyme products. Thus heterozygotes may conservatively have been incorrectly classified as homozygotes. These deviations are, therefore, not ascribed any biological significance and the Lap loci were excluded from analyses of ageand growth-heterozygosity correlations.

Due to the large number of alleles and genotypes observed at the different loci, conformity to HardyWeinberg equilibrium was also tested using chi-square statistics with only 3 groups: homozygotes for the most common allele, heterozygotes for this allele and all other alleles, and all remaining homozygotes and heterozygotes. By using this procedure significant
Hardy-Weinberg deviations were reduced to 3: Gpi at Anddammen $\left(\chi^{2}=9.749, p=0.002\right)$ and Jan Mayen $\left(\chi^{2}=5.194, \mathrm{p}=0.023\right)$, and Lap-1 at Moffen $\left(x^{2}=8.112\right.$, $p=0.004)$. In all 3 cases there were less heterozygotes than expected under Hardy-Weinberg equilibrium.

At Jan Mayen and Moffen the allele frequency data presented in Table 1 represent the results of analyses of scallops from a total of 3 and 4 dredge samples, respectively. Although the size and age distributions varied significantly between these samples, no intersubsample heterogeneity in allele frequencies was found at any locus $(p>0.378)$. Thus there is evidence that all scallops taken within each area were members of the same breeding population.

Geographic variation in allele frequencies were, however, evident from the chi-square contingency analyses at the Pgm, Sod and Mdh loci (Table 2). Even if the type 1 error factor is applied (significance level should be adjusted by dividing the initial probability level by the no. of loci examined), Mdh and Pgm are significantly heterogeneous at the 0.05 level ( $p<0.05 / 6=0.008$ ). The cluster dendrogram (Fig. 2) based on Nei's genetic identity (Nei 1972) shows that the largest allele frequency resemblance is between Moffen and Bear Island, Jan Mayen takes an intermediate position and the Andddammen scallops from off the coast of northern Norway are genetically least similar to scallops from the other sampling sites. Contingency table analyses comparing only the Bear Island and Moffen scallops did not show significant allele frequency differences at single loci, but the additive $\chi^{2}$ value over the 6 loci was significant (Table 2)

The age distributions of the Moffen and Jan Mayen scallops examined electrophoretically are shown in Fig. 3. These samples only give an approximate reflection of age distribution in the 2 regions since not all dredge samples taken during the assessment survey are represented. Unpublished data of age analyses of the whole sample set confirms that there are relatively large variations in annual settlement both at Jan Mayen and Moffen (as is also the case for scallops from waters off northern Norway; Vahl 1982). Amongst the older age-classes the scallops sampled at Jan Mayen were larger than those from Moffen (Fig. 4).

Variation in allele frequencies among different yearclasses was not evident, neither at Moffen nor at Jan Mayen (Table 3). Moreover, there were no significant relationships between groups of age cohorts and single-locus or multiple-locus heterozygosity (Table 4 , Fig. 5).

The 1-way ANOVA model testing growth of individuals $\leq 13$ yr (those still in the growth phase; $c f$. Fig. 4) as a function of single-locus heterozygosity revealed no difference in mean growth between 
Table 1. Chlamys islandica. Allele frequencies and $F_{15}$ values (in parenthesis) for individual alleles at 6 polymorphic loci. A: allele designation; p: allele frequency: $2 N$ : number of genomes (twice the no. of scallops scored); $H$ : observed $\left(H_{o}\right)$ and expected $\left(H_{e}\right)$ frequency of hetereozygotes

\begin{tabular}{|c|c|c|c|c|c|c|c|c|c|}
\hline \multirow[t]{2}{*}{ Locus } & \multirow[t]{2}{*}{ A } & \multicolumn{2}{|c|}{ Anddammen } & \multicolumn{2}{|c|}{ Jan Mayen } & \multicolumn{2}{|c|}{ Moffen } & \multicolumn{2}{|c|}{ Bear Island } \\
\hline & & p & $F_{\mathrm{IS}}$ & $\mathrm{p}$ & $F_{i S}$ & p & $F_{\mathrm{IS}}$ & $\mathrm{p}$ & $F_{\mathrm{IS}}$ \\
\hline \multirow[t]{12}{*}{$G p i$} & 33 & 0.016 & $(-0.016)$ & 0.017 & $(-0.017)$ & 0.018 & $(-0.018)$ & 0.003 & $(-0.003)$ \\
\hline & 62 & 0.047 & $(-0.049)$ & 0.053 & $(-0.056)$ & 0.054 & $(+0.014)$ & 0.077 & $(+0.077)$ \\
\hline & 71 & 0.119 & $(-0.135)^{\circ}$ & 0.143 & $(+0.007)$ & 0.113 & $(-0.056)$ & 0.111 & $(-0.009)$ \\
\hline & 85 & 0.000 & $(\ldots)$ & 0.001 & $(-0.001)$ & 0.003 & $(-0.003)$ & 0.000 & \\
\hline & 88 & 0.174 & $(+0.034)$ & 0.155 & $(+0.028)$ & 0.142 & $(+0.012)$ & 0.176 & $(-0.057)$ \\
\hline & 96 & 0.006 & $(-0.006)$ & 0.003 & $(-0.003)$ & 0.004 & $(-0.004)$ & 0.003 & $(-0.003)$ \\
\hline & 100 & 0.285 & $(+0.195)^{\cdots}$ & 0.314 & $(+0.089)^{\circ}$ & 0.311 & $(+0.078)$ & 0.315 & $(+0.145)$ \\
\hline & 108 & 0.199 & $(-0.028)$ & 0.179 & $(+0.023)$ & 0.214 & $(+0.113)^{\cdots}$ & 0.188 & $(+0.030)$ \\
\hline & 117 & 0.127 & $(+0.137)^{\circ}$ & 0.121 & $(-0.023)$ & 0.118 & $(-0.014)$ & 0.114 & $(+0.097)$ \\
\hline & 122 & 0.027 & $(+0.119)$ & 0.014 & $(+0.099)^{\circ}$ & 0.024 & $(-0.025)$ & 0.014 & $(-0.014)$ \\
\hline & $2 N$ & 512 & & 1304 & & 1114 & & 352 & \\
\hline & $H_{0}\left(H_{\mathrm{e}}\right)$ & 0.773 & $(0.815)$ & 0.784 & $(0.807)$ & 0.777 & $(0.807)$ & 0.761 & $(0.803)$ \\
\hline \multirow[t]{8}{*}{$M d h$} & 42 & 0.002 & $(-0.002)$ & 0.003 & $(-0.003)$ & 0.001 & $(-0.001)$ & 0.000 & \\
\hline & 100 & 0.680 & $(+0.007)$ & 0.676 & $(+0.069)$ & 0.644 & $(+0.017)$ & 0.672 & $(-0.049)$ \\
\hline & 171 & 0.228 & $(+0.012)$ & 0.197 & $(+0.135)^{\cdots}$ & 0.206 & $(+0.040)$ & 0.156 & $(+0.020)$ \\
\hline & 200 & 0.002 & $(-0.002)$ & 0.001 & $(-0.001)$ & 0.000 & $(\ldots)$ & 0.000 & \\
\hline & 207 & 0.002 & $(-0.002)$ & 0.000 & $(\ldots)$ & 0.000 & $(\ldots)$ & 0.003 & $(-0.003)$ \\
\hline & 214 & 0.087 & $(+0.002)$ & 0.123 & $(+0.166)^{\cdots} \cdots$ & 0.149 & $(-0.032)$ & 0.169 & $(+0.025)$ \\
\hline & $2 N$ & 518 & & 966 & & 1100 & & 372 & \\
\hline & $H_{0}\left(H_{\mathrm{e}}\right)$ & 0.475 & $(0.479)$ & 0.435 & $(0.489)$ & 0.515 & $(0.521)$ & 0.500 & $(0.495)$ \\
\hline \multirow[t]{8}{*}{ Pgm } & 87 & 0.004 & $(-0.004)$ & 0.001 & $(-0.001)$ & 0.001 & $(-0.001)$ & 0.011 & $(-0.011)$ \\
\hline & 89 & 0.217 & $(+0.080)$ & 0.168 & $(+0.048)$ & 0.190 & $(-0.019)$ & 0.183 & $(+0.025)$ \\
\hline & 95 & 0.014 & $(+0.275) \cdots$ & 0.010 & $(-0.011)$ & 0.011 & $(-0.012)$ & 0.008 & $(-0.008)$ \\
\hline & 100 & 0.679 & $(+0.030)$ & 0.631 & $(+0.019)$ & 0.661 & $(+0.044)$ & 0.712 & $(-0.018)$ \\
\hline & 105 & 0.083 & $(+0.069)$ & 0.189 & $(+0.049)$ & 0.133 & $(-0.017)$ & 0.087 & $(+0.037)$ \\
\hline & 110 & 0.002 & $(-0.002)$ & 0.001 & $(-0.001)$ & 0.003 & $(-0.003)$ & 0.000 & $()$. \\
\hline & $2 N$ & 492 & & 1436 & & 1140 & & 388 & \\
\hline & $H_{\mathrm{o}}\left(H_{\mathrm{e}}\right)$ & 0.455 & $(0.485)$ & 0.519 & $0.538)$ & 0.504 & $(0.508)$ & 0.450 & $(0.452)$ \\
\hline \multirow[t]{7}{*}{ Sod } & 40 & 0.125 & $(-0.036)$ & 0.121 & $(+0.076)^{\circ}$ & 0.130 & $(-0.041)$ & 0.120 & $(-0.087)$ \\
\hline & 62 & 0.000 & (. . ) & 0.000 & & 0.003 & $(+0.666) \cdots$ & 0.000 & \\
\hline & 71 & 0.051 & $(-0.053)$ & 0.093 & $(+0.024)$ & 0.079 & $(+0.010)$ & 0.052 & $(-0.055)$ \\
\hline & 100 & 0.822 & $(-0.056)$ & 0.786 & $(+0.006)$ & 0.789 & $(+0.045)$ & 0.827 & $(-0.136)$ \\
\hline & 125 & 0.002 & $(-0.002)$ & 0.000 & $(\ldots)$ & 0.000 & $(\ldots)$ & 0.000 & \\
\hline & $2 N$ & 512 & & 1494 & & 1150 & & 382 & \\
\hline & $H_{\circ}\left(H_{e}\right)$ & 0.320 & $(0.306)$ & 0.348 & $(0.359)$ & 0.350 & $(0.355)$ & 0.330 & $(0.298)$ \\
\hline \multirow[t]{8}{*}{ Lap-1 } & 96 & 0.000 & & 0.000 & $()$. & 0.001 & $(-0.001)$ & 0.000 & \\
\hline & 98 & 0.250 & $(-0.333)$ & 0.147 & $(+0.297)$ & 0.181 & $(+0.199) \cdots$ & 0.222 & $(+0.017)$ \\
\hline & 100 & 0.500 & $(+0.500)$ & 0.559 & $(+0.165)$ & 0.518 & $(+0.128)^{\cdots}$ & 0.504 & $(-0.009)$ \\
\hline & 102 & 0.125 & $(-0.143)$ & 0.235 & $(+0.346)$ & 0.125 & $(+0.171) \cdots$ & 0.152 & $(+0.023)$ \\
\hline & 104 & 0.125 & $(-0.143)$ & 0.059 & $(-0.063)$ & 0.174 & $(+0.181) \cdots$ & 0.117 & $(+0.119)$ \\
\hline & $\mathrm{x}$ & 0.000 & 1.1 & 0.000 & & 0.000 & $(\ldots)$ & 0.004 & $(-0.004)$ \\
\hline & $2 N$ & 16 & & 34 & & 992 & & 230 & \\
\hline & $H_{0}$ & $\left(H_{e}\right) 0.62$ & $5(0.656)$ & 0.471 & $(0.607)$ & 0.546 & $(0.653)$ & 0.643 & $(0.660)$ \\
\hline \multirow[t]{6}{*}{ Lap-2 } & 98 & 0.028 & $(-0.029)$ & 0.122 & $(+0.050)$ & 0.132 & $(+0.096)$ & 0.141 & $(-0.012)$ \\
\hline & 100 & 0.778 & $(+0.357)$ & 0.561 & $(+0.047)$ & 0.628 & $(+0.069)$ & 0.580 & $(-0.045)$ \\
\hline & 102 & 0.194 & $(+0.468)^{\circ}$ & 0.316 & $(+0.104)$ & 0.236 & $(+0.075)$ & 0.270 & $(+0.035)$ \\
\hline & 104 & 0.000 & $(\quad)$. & 0.000 & $(\quad)$. & 0.004 & $(-0.004)$ & 0.009 & $(-0.009)$ \\
\hline & $2 N$ & 36 & & 98 & & 512 & & 326 & \\
\hline & $H_{0}\left(H_{e}\right)$ & 0.222 & $(0.356)$ & 0.531 & $(0.570)$ & 0.492 & $(0.532)$ & 0.577 & $(0.571)$ \\
\hline
\end{tabular}


Table 2. Chlamys islandica. Contingency chi-square analyses of inter-region heterogeneity in allele frequencies at 6 polymorphic loci, for all 4 regions (Anddammen, Jan Mayen, Moffen and Bear Island), and for comparison of Moffen and Bear Island specimens only. $p=$ significance level. Sample sizes are evident from Table 1

\begin{tabular}{|lrrrrrcc|}
\hline & \multicolumn{3}{c}{ All 4 regions } & \multicolumn{3}{c|}{ Moffen/Bear Island } \\
Locus & \multicolumn{1}{c}{$\chi^{2}$} & $\mathrm{df}$ & $\mathrm{p}$ & $\chi^{2}$ & $\mathrm{df}$ & $\mathrm{p}$ \\
\hline Gpi & 27.897 & 21 & 0.143 & 11.283 & 7 & 0.127 \\
Mdh & 19.869 & 6 & 0.003 & 4.867 & 2 & 0.088 \\
Pgm & 53.382 & 9 & $<0.001$ & 6.324 & 3 & 0.097 \\
Sod & 13.324 & 6 & 0.038 & 4.049 & 2 & 0.132 \\
Lap-1 & 12.554 & 9 & 0.184 & 6.699 & 3 & 0.082 \\
Lap-2 & 9.497 & 6 & 0.147 & 1.945 & 2 & 0.378 \\
Additive & 136.523 & 57 & $<0.001$ & 35.167 & $19<0.01$ \\
\hline
\end{tabular}

homozygotes and heterozygotes for any locus (Table 5; $t$-tests confirmed homogeneity of variances between pairs of means, $0.242<\mathrm{p}<0.967$ ). Moreover, plots of growth and heterozygosity classes (Fig. 6) provided no evidence that growth increased with increasing numbers of heterozygous loci and no effect of multiplelocus heterozygosity on growth is evident from data presented in Table $5\left(H_{4}\right)$.

The only class variable that appeared to affect growth was subsample within region (Table 5), i.e. the size attained within a particular age-group differed among subsamples, possibly as a consequence of variable growth conditions within the limited geographic distribution of a given breeding population. This intersample variation in growth was not reflected in allele frequency differences between the same subsamples (above) nor did single-locus heterozygosity or average heterozygosity over all loci vary among subsamples
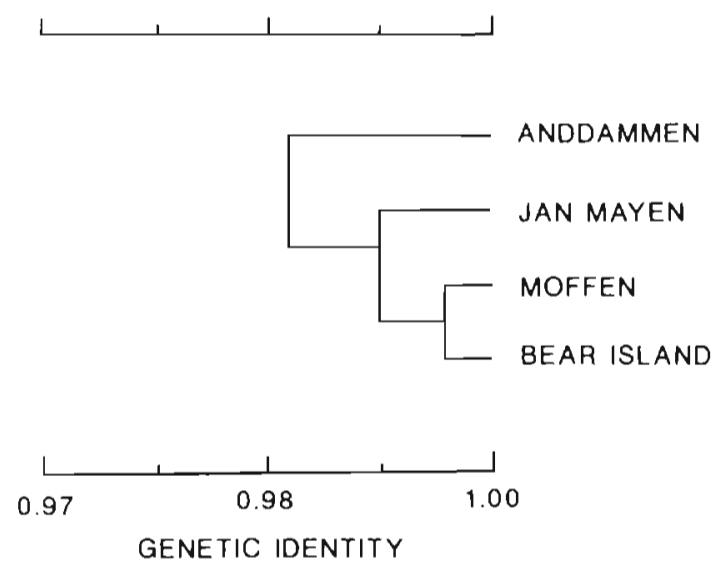

Fig. 2. Chlamys islandica. Cluster dendrogram based on Nei's (1972) genetic identity for pairwise comparison of samples across the 6 investigated polymorphic loci

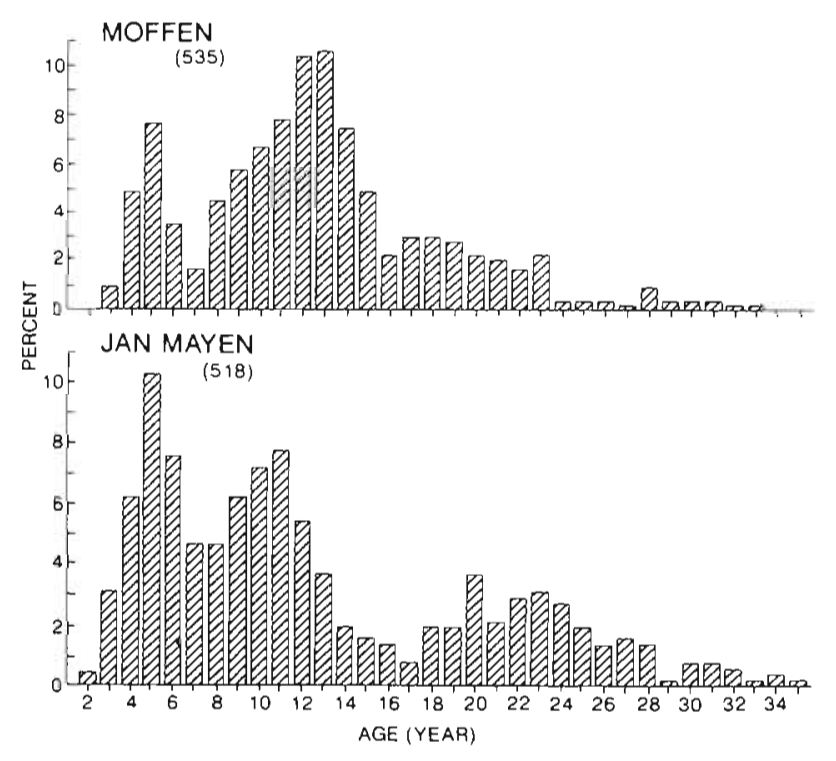

Fig. 3. Chlamys islandica. Percentage age distribution at Moffen and Jan Mayen. The no. of individuals aged at each locality is given in parentheses

within any of the 2 regions $(\mathrm{p}>0.307$ and $\mathrm{p}>0.390$ for single-locus and multiple-locus heterozygosity, respectively; chi-square analyses).

Over all cohorts sex differences in single-locus or multiple-locus heterozygosity were not found ( $p>0.06$ and $p>0.27$ respectively; chi-square tests).

\section{DISCUSSION}

The 4 polymorphic loci Gpi, Pgm, Sod and Mdh exhibited consistent banding patterns. With few exceptions, there was conformity to Hardy-Weinberg expectations, suggesting that the isozyme variants are genetically based. The banding pattern of 1 of the 2 loci coding for LAP revealed highly significant deviations from Hardy-Weinberg expectations with consistent deficits of heterozygotes. There is reason to believe that this could arise as a result of inactivation of alleles so that heterozygotes have been misinterpreted as homozygotes. Thus, caution should be exercised in using data relating to Lap loci as stock markers in Chlamys islandica. Nevertheless, even though the numbers of Lap heterozygotes may have been underestimated, the heterozygosity measured at the Lap loci was high (for Lap-1 $H_{\exp }=0.644$ averaged over the 4 sampling sites) and much higher than measured for the related Chlamys varia (Beaumont \& Beveridge 1984; $H_{\text {exp }}=0.292$ ). These authors found Lap to be monomorphic in $C$. opercularis, and variable, but with inconsistent staining patterns, in $C$. distorta and Pecten maximus. The Lap-1 heterozygosity measured in the 


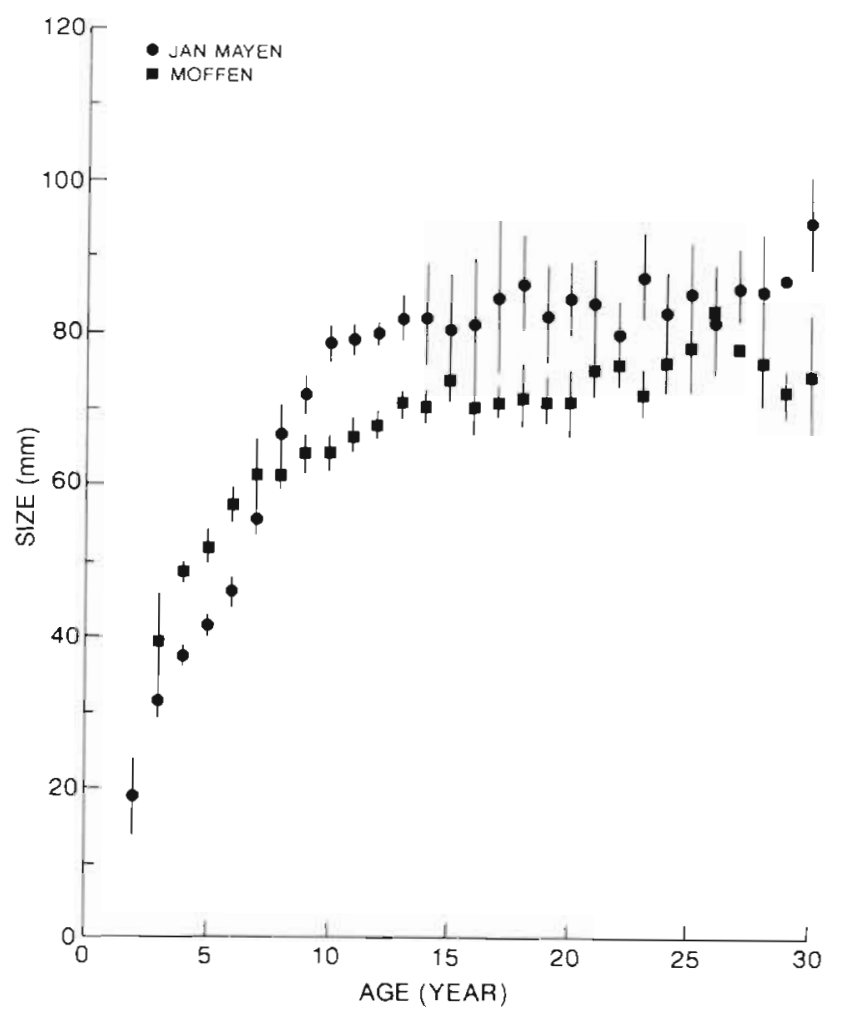

Fig. 4. Chlamys islandica. Plots of size versus age in samples from Jan Mayen and Moffen (mean $\pm \mathrm{SE}$ )

Iceland scallop in the present study, in addition to being higher than that of other pectinids, is also slightly higher than Lap-heterozygosities for the common mussel Mytilus edulis in Norwegian waters (Fevolden \& Garner 1986) and is significantly higher than for European oyster Ostrea edulis in Scandinavian waters (Johannesson et al. 1989).

The $M d h$ heterozygosity found in the present study for Chlamys islandica is also high (mean of $H_{\text {exp }}=$ 0.496), being considerably higher than Beaumont \& Beveridge (1984) reported for C. opercularis (0.100), C. distorta (0.125), and Pecten maximus (0.094); C. varia was monomorphic for Mdh. Very low Mdh heterozygosity is reported in northern populations of Mytilus edulis (Fevolden \& Garner 1986) and Ostrea edulis (Johannesson et al. 1989). Thus, taken together with the previously reported high variation at the 3 loci Gpi, Pgm, and Sod (Fevolden 1989), the present information on $L a p$ and $M d h$ strengthens the case for classifying $C$. islandica as an organism with exceptional variation at several gene loci, its subpolar habitat notwithstanding.

One may only speculate about why this particular cold-water species shows such high variability at the examined loci. The thermal environment of the Iceland scallop is stable throughout the year, which according to classical models of adaptive significance of gene polymorphism favours low genetic variability (Grassle \& Sanders 1973; see Fevolden 1989 for models with special reference to bivalves). During the many months with little or no daylight the primary production, and hence biodeponation, is very low in northern waters. This may be expected to severely reduce food availability for Chlamys islandica. This scallop species, however, tends to inhabit areas with strong currents (Wiborg 1963), which may tend to counteract seasonal variation in food supply. In general, this may provide favourable conditions for benthic filter feeders. This suggests that food quality rather than food quantity may be the unstable component of the environment in which the Iceland scallop lives. Models have been presented that ascribe to there being positive correlations between trophic diversity and enzyme polymorphism (e.g. Nelson \& Hedgecock 1980).

The degree of heterozygosity has been suggested to relate to basal metabolism (see e.g. Koehn \& Shumway 1982, Hawkins et al. 1986), with increased heterozygosity enabling an individual to reduce the metabolic costs of body maintenance. If this applies in the case of the polymorphic loci of Chlamys islandica, the higher energetic efficiency associated with heterozygosity at the surveyed loci, or linked loci, may lead to improved survival in the harsh environment. Thus during evolutionary time, high means of heterozygosity at these loci might be expected. On the other

Table 3. Ch/amys islandica. Contingency chi-square analyses of heterogeneity among year-classes in allele frequencies at the polymorphic loci. Ten year-classes are compared at Jan Mayen (Age 4 to Age 13), 11 at Moffen (Age 4 to Age 15, minus Age 7). $2 N=$ number of genomes (twice the no. of scallops); $\mathrm{p}=$ significance level

\begin{tabular}{|lrrrrrrrr}
\hline \multirow{2}{*}{ Locus } & \multicolumn{4}{c}{ Moffen } & & \multicolumn{2}{c}{ Jan Mayen } \\
& $2 N$ & $x^{2}$ & $\mathrm{df}$ & $\mathrm{p}$ & $2 N$ & $x^{2}$ & $\mathrm{df}$ & $\mathrm{p}$ \\
\hline Gpi & 764 & 51.458 & 40 & 0.106 & 544 & 38.936 & 36 & 0.339 \\
Mdh & 760 & 28.502 & 20 & 0.098 & 366 & 6.632 & 9 & 0.675 \\
Pgm & 786 & 16.965 & 20 & 0.655 & 618 & 13.350 & 18 & 0.770 \\
Sod & 792 & 23.921 & 20 & 0.246 & 646 & 18.51 .1 & 18 \\
Lap-1 & 686 & 33.916 & 30 & 0.284 & & & 0.422 \\
Lap-2 & 338 & 4.056 & 10 & 0.945 & & \\
\hline
\end{tabular}


Table 4. Chlamys islandica. Contingency chi-square analyses of frequencies of homozygotes and heterozygotes for 4 polymorphic loci in 6 different age-groups (same grouping as in Fig. 5) and for frequencies of individuals with different number of heterozygous loci $\left(\mathrm{H}_{4}: \mathrm{O}\right.$ to 4$)$ in the same age-groups, $\mathrm{N}=$ sample size; $\mathrm{p}=$ significance level

\begin{tabular}{|lcccccccc|}
\hline Locus & \multicolumn{3}{c}{ Moffen } & & \multicolumn{3}{c|}{ Jan Mayen } \\
& $N$ & $x^{2}$ & df & $p$ & $N$ & $x^{2}$ & df \\
\hline Gpi & 573 & 3.879 & 5 & 0.567 & 559 & 1.359 & 5 & 0.929 \\
Mdh & 550 & 3.571 & 5 & 0.613 & 332 & 2.443 & 5 & 0.785 \\
Pgm & 570 & 1.798 & 5 & 0.876 & 565 & 3.929 & 5 & 0.560 \\
Sod & 575 & 10.893 & 5 & 0.055 & 596 & 6.539 & 5 & 0.257 \\
$H_{4}$ & 546 & 9.269 & 15 & 0.863 & 287 & 8.333 & 10 & 0.596 \\
\hline
\end{tabular}

hand, the phenomenon of high single-locus or multiple-locus heterozygosity seems to be by no means universal among Arctic marine species. There is little documented evidence relating to electrophoretic variability of other species from Jan Mayen or Spitsbergen waters, but 3 species of liparid fish taken off Spitsbergen showed extremely low intra-specific genetic variability (Fevolden et al. 1989).

The relatively few significant deviations from the Hardy-Weinberg expectation of genotype distributions found in the present study contrast with the trends observed in several other pectinids (Beaumont \& Zouros 1991). Deviations that were observed in the present study were mainly caused by a deficit of heterozygotes, a frequently reported observation for marine bivalves (Zouros \& Foltz 1984). The Iceland scallop has large breeding units and a reproductive strategy that combines long life with the production of large numbers of eggs and sperm (thereby offering a high potential for reproductive success), and this does not favour inbreeding as a likely explanation for a defi- ciency of heterozygotes. From theoretical considerations null alleles have been considered to be unlikely causes for the deficit in other bivalves (Zouros et al. 1980, Gosling 1989), leaving selection the most plausible cause for observed Hardy-Weinberg deviations. In the present case, however, it may seem somewhat devisive to suggest that there may be a heterozygous disadvantage for a locus (Gpi) at which approximately $80 \%$ of the individuals are heterozygous.

Inter-area differences in allele frequencies strengthen arguments that the different breeding stocks of Chlamys islandica are at least partially isolated from one another. It was suggested earlier (Fevolden 1989) that prevailing currents may be disfavourable for extensive gene flow between the 4 major regions. The fact that scallops of the Bear Island and Moffen populations appeared to be most similar in allele frequencies (Fig. 2) does not conflict with the surface current system (Fig. 1). Some dispersal of larvae may occur from Bear Island along the coast of Spitsbergen to Moffen, although this would be difficult to substanti-
Fig. 5. Chlamys islandica Relationship between heterozygosity (no. of heterozygous loci, mean $\pm \mathrm{SE}$ ) and age-groups from Moffen and Jan Mayen. Number of scallops in each age-group is given in parentheses

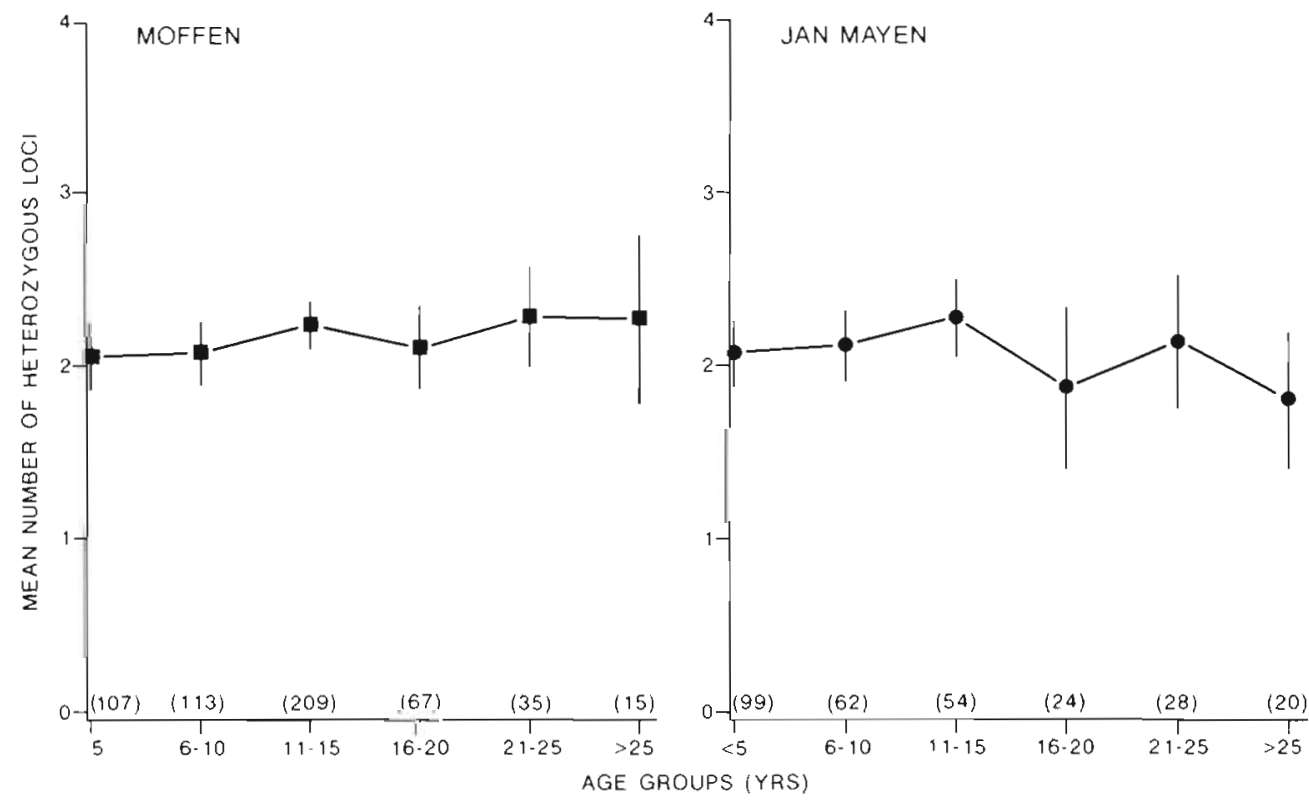




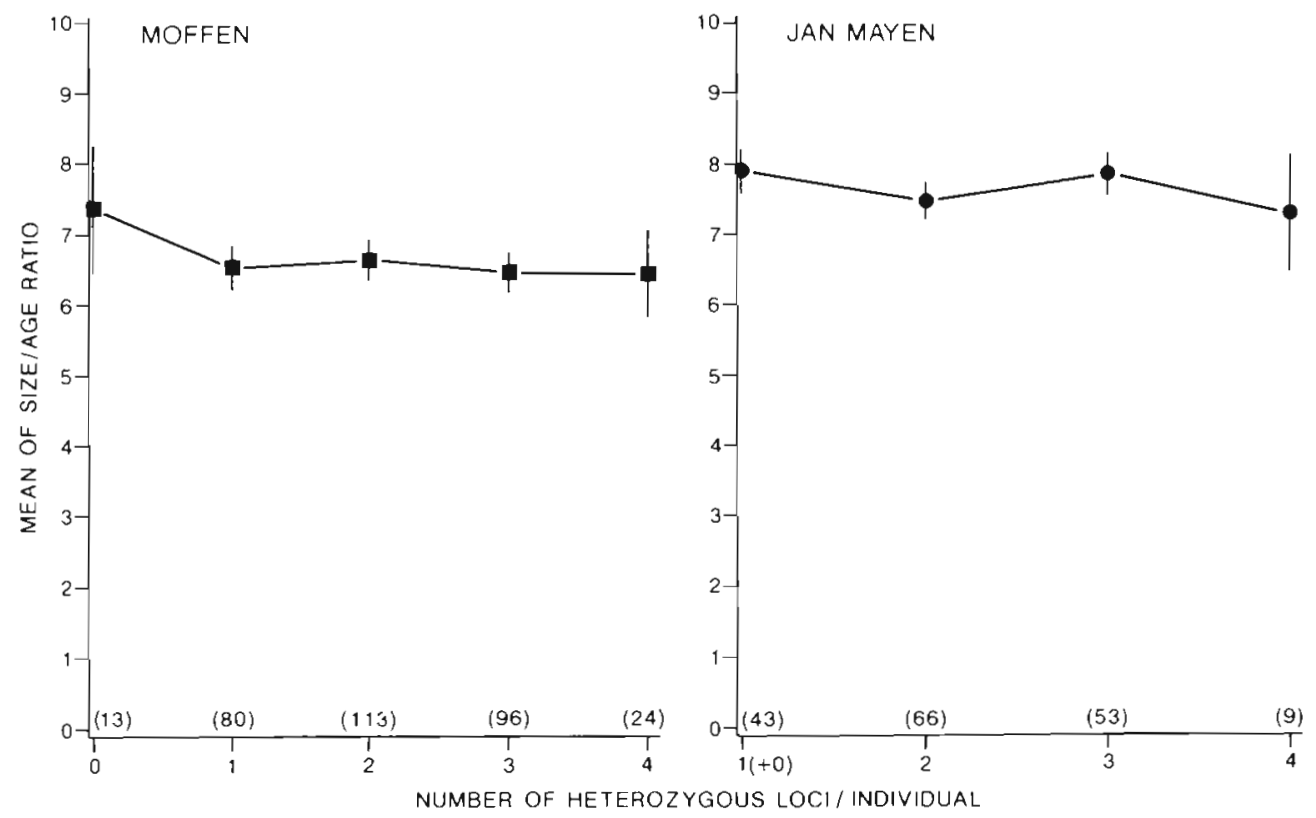

Fig. 6. Chlamys islandica. Relationship between size/ age ratios (index of growth, mean $\pm \mathrm{SE}$ ) and number of loci for which the scallops are heterozygous. Sample sizes in parentheses

ate. It has been pointed out that the origin of spat settling on a scallop bed and the extent of larval dispersal are difficult to estimate and are not known with any degree of certainty for any scallop species (Duggan 1987, cited by Brand 1991).

The general lack of significant differences in allele frequencies between year-classes at Jan Mayen and Moffen, strengthens the suggestion made earlier (Fevolden 1989) that genetic drift is not a probable explanation for the spatial variation in allele frequencies. Selective forces cannot be entirely dismissed as an explanatory factor, however, the relative contribution from neutral factors, i.e. restricted gene flow, and selective factors are always difficult to assess. The suggestion that the different areas should be managed as if they represented semi-discrete genetic units (Fevolden 1989), should, therefore, be upheld.
It should be noted that the present Andammen samples are very similar in allele frequencies to the Tromsø/Berg sample of Fevolden (1989) taken ca $60 \mathrm{~km}$ further south. This means that despite complicated current patterns in the archipelago of northern Norway, extensive gene flow between scattered scallop beds seems possible.

The present data have not demonstrated that singlelocus or multiple-locus heterozygosity affects longevity of Chlamys islandica; heterozygosity did not increase with age of the scallops (or decrease, as reported for Gpi heterozygosity of Pecten maximus; Wilkins 1978). Moreover growth was not shown to increase with increasing number of heterozygous loci. These results contrast with the positive growth-heterozygosity correlations presented for other bivalves such as Mytilus edulis (Koehn \& Gafney 1984), Mulinia lateralis

Table 5. Chlamys islandica. ANOVA for growth as a function of (1) single locus heterozygosity (2 classification levels: heterozygote or homozygote). (2) heterozygosity over 4 loci $\left(H_{4} ; 5\right.$ classification levels: 0 to 4$)$ and (3) subsample at each locality (4 at Moffen, 3 at Jan Mayen). Sample size (N), F-values and significance levels are given

\begin{tabular}{|c|c|c|c|c|c|c|c|c|}
\hline \multirow[t]{2}{*}{ Locus } & \multicolumn{4}{|c|}{ Moffen } & \multicolumn{4}{|c|}{ Jan Mayen } \\
\hline & $N$ & $\mathrm{df}$ & $F$ & $\mathrm{p}$ & $N$ & $\mathrm{df}$ & $F$ & $\mathrm{p}$ \\
\hline$G p i$ & 340 & 1 & 0.01 & 0.908 & 323 & 1 & 0.07 & 0.796 \\
\hline$M d h$ & 328 & 1 & 0.75 & 0.389 & 196 & 1 & 0.25 & 0.621 \\
\hline $\mathrm{Pgm}$ & 339 & 1 & 0.31 & 0.580 & 330 & 1 & 0.01 & 0.909 \\
\hline Sod & 342 & 1 & 1.17 & 0.279 & 344 & 1 & 0.00 & 0.953 \\
\hline$H_{4}$ & 326 & 4 & 1.13 & 0.340 & 171 & 4 & 1.45 & 0.218 \\
\hline Subsample & 343 & 3 & 27.39 & $<0.001$ & 346 & 2 & 21.90 & $<0.001$ \\
\hline
\end{tabular}


(Koehn et al. 1988), Crassostrea virginica (Zouros et al. 1980) and Macoma balthica (Green et al. 1983). Gosling (1989) however reported that highly heterozygous individuals from $M$. edulis populations off the west coast of Ireland did not achieve higher and more uniform growth rates than homozygous individuals of the same age cohort and Gentili \& Beaumont (1988) showed that a positive correlation between heterozygosity and growth rate was only observed in $M$. edulis reared at high densities. Lack of positive correlations between multiple-locus heterozygosity and growth rate has also been reported for the pectinids Placopecten magellanicus (Foltz \& Zouros 1984, Volckaert \& Zouros 1989) and Pecten maximus (Beaumont et al. 1985), and it may be that this feature is the norm rather than the exception in Pectinidae.

Some of the studies indicating positive correlations between growth and heterozygosity were carried out on young and newly settled organisms, and almost always on cohorts of bivalves which were all of the same age. Comparison with field data of post-juvenile organisms representing many year-classes may, therefore, be invalid. For example, it has been shown that some of the positive correlations between growth and heterozygosity for Mytilus edulis changed in older samples of the same cohort (Diehl \& Koehn 1985). Cultivation of Chlamys islandica is still in a very preliminary and experimental phase. Thus, before rejecting heterozygosity as a factor of importance for growth under farmed conditions, laboratory experiments should be carried out under conditions of controlled environments and known rates of food supply.

Acknowledgements. This work was supported by grants from The Norwegian Council of Fishery Research to the University of Oslo, Div. of Marine Zoology, and to the University of Tromsa, College of Fishery Science. Michaela Aschan and Jan Sundet are thanked for providing unpublished data on age distribution of scallops from Moffen and Jan Mayen. Professor Malcolm Jobling is thanked for suggesting improvements to the manuscript.

\section{LITERATURE CITED}

Beaumont, A. R. (1991). Allozyme data and scallop stock identification. J. Cons. int. Explor. Mer 47: 333-338

Beaumont, A. R., Beveridge, C. M. (1984). Electrophoretic survey of genetic variation in Pecten maximus, Chlamys opercularis, C. varia and C distorta from the Irish Sea. Mar. Biol. 81: 299-306

Beaumont, A. R., Gosling, E. M., Beveridge, C. M., Budd, M. D., Burnell, C. M. (1985). Studies on heterozygosity and growth rate in the scallop Pecten maximus (L.). In: Gibbs, P. E. (ed.) Proc. 19th Eur. Mar. Biol. Symp. Cambridge University Press, Cambridge, p. 443-455

Beaumont, A. R., Zouros, E. (1991). Genetics of scallops. In: Shumway, S. E. (ed.) Scallops: biology, ecology and aquaculture. Elsevier, Amsterdam, p. 585-623
Brand, A. R. (1991). Scallop ecology: distribution and behaviour. In: Shumway, S. E. (ed.) Scallops: biology, ecology and aquaculture. Elsevier, Amsterdam, p. 517-584

Clayton, J. W., Tretiak, D. W. (1972). Amine-citrate buffers for $\mathrm{pH}$ control in starch gel electrophoresis. J. Fish. Res. Bd Can. 29: 1169-1172

Diehl, W., Koehn, R. K. (1985). Multiple-locus heterozygosity, mortality and growth in a cohort of Mytilus edulis. Mar Biol. 88: 256-271

Duggan, N. A. (1987). Recruitment in North Irish Sea scallop stocks. Ph.D. thesis, University of Liverpool. (Cited by Brand 1991)

Ekman, S. (1953). Zoogeography of the sea. Sidgwick \& Jackson, London

Fevolden, S. E. (1989). Genetic differentiation of the Iceland scallop Chlamys islandica (Pectinidae) in the northern Atlantic Ocean. Mar. Ecol. Prog. Ser. 51: 77-85

Fevolden, S. E., Ayala, F. J. (1981). Enzyme polymorphism in Antarctic krill (Euphausiacea); genetic variation between populations and species. Sarsia 66: $167-181$

Fevolden, S. E., Garner, S. P. (1986). Population genetics of Mytilus edulis (L.) from Oslofjorden, Norway, in oilpolluted and non oil-polluted water. Sarsia 71: 247-257

Fevolden, S. E., Haug, T., Vader, W. (1989). Intra- and interspecific allozymic variation in Liparis fabricii and Liparis gibbus (Teleostei, Liparididae) from Spitsbergen waters. Polar Biol. 10: 107-111

Foltz, D. W., Zouros, E. (1984). Enzyme heterozygosity in the scallop Placopecten magellanicus (Gmelin) in relation to age and size. Mar. Biol. Lett. 5: 255-263

Gentili, M. R., Beaumont, A. R. (1988). Environmental stress, heterozygosity, and growth rate in Mytilus edulis L. J. exp. mar. Biol. Ecol. 120: 145-153

Gosling, E. M. (1989). Genetic heterogeneity and growth rate in a cohort of Mytilus edulis from the Irish coast. Mar. Biol. 100: $211-215$

Grassle, J. F., Sanders, H. L. (1973). Life histories and the role of disturbance. Deep Sea Res. 20: 643-659

Green, R. H., Singh, S. M., Hicks, B., McCuaig, J. M. (1983). An Arctic intertidal population of Macoma balthica (Mollusca, Pelecypoda): genetic and phenotypic components of population structure. Can. J. Fish. Aquat. Science 40: 1360-1371

Gruffydd, L. D. (1975). The development of the larvae of Chlamys islandica in the plankton and its salinity tolerance in the laboratory (Lammellibranchia, Pectinidae). Astarte 8: 61-67

Hawkins, A. J. S., Bayne, B. L., Day, A. J. (1986). Protein turnover, physiological energetics and heterozygosity in the blue mussel Mytilus edulis: the basis of variable agespecific growth. Proc. R. Soc. (Ser. B) 229: 161-176

Johannesen, O. H. (1973). Age determination in Chlamys islandica (O. F. Müller). Astarte 6: 15-20

Johannesson, K., Rödström, E. M., Aase, H. (1989). Low genetic variability in Scandinavian populations of Ostrea edulis L. - possible causes and implications. J. exp. mar Biol. Ecol. 128: 177-190

Koehn, R. K., Diehl, W. J., Scott, T M. (1988). The differential contribution by individual enzymes of glycolysis and protein catabolism to the relationship between heterozygosity and growth rate in the coot clam Mulnia lateralis. Genetics, Baltimore, Md 118: 121-130

Koehn, R. K, Gaffney, P. M. (1984). Genetic heterozygosity and growth rate in Mytilus edulis. Mar. Biol. 82:1-7

Koehn, R. K., Shumway, S. E. (1982). A genetic/physiological explanation for the differential growth rate among individuals of the American oyster, Crassostrea virginica (Gmelin). Mar. Biol. Lett. 3: 35-42 
Li, C. C. (1955). Population genetics. University of Chicago Press, Chicago

Nei, M. (1972). Genetic distance between populations. Am. Nat. 106: 283-292

$\mathrm{Nei}_{2} \mathrm{M}$. (1977). F-statistics and analysis of gene diversity in subdivided populations. Ann. hum. Genet. 41: 225-233

Nelson, K., Hedgecock, D. (1980). Enzyme polymorphism and adaptive strategy in the decapod Crustacea. Am. Nat. 116: $238-280$

Ridgway, G. J., Sherburne, S. W., Lewis R. D. (1970). Polymorphism in the esterases of Atlantic herring. Trans. Am. Fish. Soc. 99: 147-151

Swofford, D. L., Selander, R. B. (1981). BIOSYS-1: a FORTRAN program for the comprehensive analysis of electrophoretic data in population genetics and systematics. J. Hered. 72: 281-283

Vahl, O. (1982). Long term variation in recruitment of the Iceland scallop Chlamys islandica from northern Norway. Neth. J. Sea Res. 16: 80-87

Volkaert, F., Zouros, E. (1989). Allozyme and physiological variation in the scallop Placopecten magellanicus and a general model for the effects of heterozygosity on fitness in marine molluscs. Mar. Biol. 103: 51-61

Waller, T. R. (1991). Evolutionary relationships among commercial scallops (Mollusca: Bivalvia: Pectinidae). In: Shumway, S. E. (ed.) Scallops: biology, ecology and aquaculture. Elsevier, Amsterdam, p. 1-74

This article was presented by J. Gray, Oslo, Norway
Wallace, J, C. (1982). The culture of the Iceland scallop, Chlamys islandica (O. F. Müller). I. Spat collection and growth during the first year. Aquaculture, Amsterdam 26: $311-320$

Wiborg, K. (1963). Some observations on the Iceland scallop (Chlamys islandica) (Müller) in Norwegian waters. Fisk. Dir. Skr. (Ser. Havunders.) 13: 38-53

Wilkins, N. P. (1978). Length-correlated changes in heterozygosity at an enzyme locus in the scallop (Pecten maximus L.). Anim. Blood Grps biochem. Genet. 9: 69-77

Wright, S. (1965). The interpretation of population structure by $F$-statistics with special regard to systems of mating. Evolution 19: 395-420

Zouros, E., Foltz, D. W. (1984). Possible explanations of heterozygote deficiency in bivalve molluscs. Malacologia 25: 583-591

Zouros, E., Mallet, A. L. (1989). Genetic explanations of the growth/heterozygosity correlation in marine molluscs. In: Ryland, J. S., Tyler, P. A. (eds.) Proc. 23rd Eur. Mar. Biol. Symp. Reproduction, genetics and distribution of marine organisms. Olsen \& Olsen, Fredensborg, p. 235-249

Zouros, E., Romero-Dorey, M., Mallet, A. L. (1988). Heterozygosity and growth in marine bivalves: further data and possible explanations. Evolution 42: 1332-1341

Zouros, E., Singh, S. M., Miles, H. E. (1980). Growth rate in oysters: an overdominant phenotype and its possible explanations. Evolution 31: 856-867

Manuscript first received: February 10, 1992

Revised version accepted: June 5, 1992 